\title{
Hubungan Antara Pengetahuan, Sikap dan Praktik Personal Hygiene Organ Genitalia Eksterna Terhadap Kejadian Keputihan Patologis
}

\author{
Widia A. A.Cahyaningtyas, ${ }^{1}$ Sudung Nainggolan, ${ }^{1}$ Tigor P. Simanjuntak ${ }^{2 *}$ \\ ${ }^{1}$ Departemen Ilmu Kesehatan Masyarakat Fakultas Kedokteran Universitas Kristen Indonesia \\ 2Departemen Obstetri dan Ginekologi Fakultas Kedokteran Universitas Kristen Indonesia
}

\begin{abstract}
Abstrak
Keputihan (leukorea, flour albus, vaginal discharge) adalah sekret berlebihan dari vagina selain darah haid, dan tidak disebabkan neoplasma atau penyakit sistemik. Keputihan merupakan masalah kesehatan reproduksi dialami hampir $75 \%$ perempuan didunia, paling tidak sekali selama hidupnya. Kurangnya pengetahuan, sikap, dan praktik dalam perawatan vagina diyakini berpengaruh terhadap kejadian keputihan patologis tersebut. Penelitian ini bertujuan untuk mengetahui hubungan pengetahuan, sikap, dan praktik personal hygiene organ genital eksterna terhadap kejadian keputihan patologis pada mahasiswi Fakultas Kedokteran Universitas Kristen Indonesia. Penelitian ini menggunakan desain penelitian analitik korelasional pada 98 mahasiswi. Terdapathubungan yang bermakna $(\mathrm{p}=0,000)$ dan korelasi positif antara tingkat pengetahuan, sikap dan praktik personal hygiene dengan kejadian keputihan patologis.
\end{abstract}

Kata Kunci : keputihan, pengetahuan, sikap, praktik, personal hygiene.

\section{Relationship Between Knowledge, Attitudes and Personal Practices of External Genitalia Hygiene Against Pathological Leucorrhoea}

\begin{abstract}
Vaginal discharge (leukorrhea, flour albus, vaginal discharge) is excessive discharge from the vagina other than menstrual blood, and is not caused by neoplasms or systemic disease. Leucorrhoea is a reproductive health problem that affects nearly $75 \%$ of women in the world, at least once in their lifetime. Lack of knowledge, attitude, and practice in vaginal care is believed to have an effect on the incidence of pathological vaginal discharge. This study aims to determine the relationship between knowledge, attitudes, and personal hygiene practices of external genital organs on the incidence of pathological vaginal discharge in students of the Faculty of Medicine, Christian University of Indonesia. This study used a correlational analytical research design on 98 female students of the Faculty of Medicine, Christian University of Indonesia. It was found a significant relationship $(p=0.000)$ and a positive correlation between the level of knowledge, attitudes and personal hygiene practices with the incidence of pathological vaginal discharge.
\end{abstract}

Keywords: leucorrhoea, knowledge, attitude, practice, personal hygiene.

*TPS: Penulis Koresponden; E-mail: tigorpsimanjuntak@gmail.com

Makalah ini merupakan preprint dan belum selesai menjalani proses review dan editing 


\section{Pendahuluan}

Keputihan (leukorea, flour albus, vaginal discharge) adalah sekret yang keluar secara berlebihan dari vagina selain darah haid, dan tidak disebabkan neoplasma atau penyakit sistemik. ${ }^{1}$ Keputihan bersifat fisiologis (normal) atau patologis (tidak normal), dikatakan fisiologis apabila sekret bening, tidak berbau, tidak gatal serta dapat ditemukan jumlah epitel lebih banyak dibanding leukosit, disertai dengan flora normal. ${ }^{2}$ Keputihan fisiologis memiliki $\mathrm{pH}$ berkisar 3.5-4.5, bersifat asam guna menghambat pertumbuhan mikroorganisme lain berpotensi menyebabkan keputihan. Sementara keputihan patologis adalah sekret berwarna putih/kuning/kehijauan/keabu-abuan, berbau tidak sedap dan amis (fishy odor), berjumlah banyak dan menimbulkan keluhan seperti gatal, kemerahan (eritema), edema, rasa terbakar pada daerah genital, nyeri saat berhubungan seksual (dispareunia) atau nyeri saat berkemih (disuria). ${ }^{3}$ Badan Kependudukan dan Keluarga Berencana Nasional (BKKBN) 2011 menyatakan sebesar $75 \%$ wanita di dunia yang pernah mengalami keputihan, sedangkan wanita Eropa yang mengalami keputihan sebesar 25\%. Di Indonesia sebanyak $75 \%$ wanita pernah mengalami keputihan minimal satu kali dalam hidupnya dan $45 \%$ di antaranya mengalami keputihan sebanyak dua kali atau lebih. ${ }^{4}$ Kebiasaan atau perilaku seseorang tidak memperhatikan kebersihan organ genital merupakan salah satu faktor pencetus keputihan. ${ }^{5}$ Untuk meningkatkan perilaku kesadaran menjaga kebersihan organ genital, perlu meningkatan pengetahuan dan sikap menjaga kebersihan organ genital. Sebab pengetahuan berperan penting membentuk tindakan seseorang (overt behaviour) dan sikap kesiapan untuk menciptakan tindakan sebagai reaksi terhadap objek-objek dilingkungan sekitar. ${ }^{6,7}$

Keputihan patologisberhubungandengan pengetahuan, sikap dan praktik personal hygiene organ genitalia eksterna. Bau tidak sedap dan gatal menimbulkan rasa tidak nyaman bagi perempuan yang mengalami, hal ini berdampak buruk pada konsentrasi belajar dan kegiatan perkuliahan, menimbulkan rasa percaya diri rendah berakibat terganggunya kehidupan sosial. ${ }^{8}$ Oleh sebab penulis ingin mengetahui korelasi antara keputihan patologis dengan pengetahuan, sikap dan praktik personal hygiene organ genitalia eksterna pada mahasiswakedokteran.

\section{Metode Penelitian}

Penelitian menggunakan desain analitik korelasional untuk mengetahui nilai kemaknaan dan korelasian antara pengetahuan, sikap dan praktik personal hygiene organ genitalia eksterna pada 98 mahasiswi Fakultas Kedokteran Universitas Kristen Indonesia angkatan 2019 yang bersedia menjadi responden dan mengisi lembar kuesioner, dilakukan periode Juni September 2019.

Data digunakan data primer dikumpulkan dengan menggunakan kuesioner telah diuji validitas serta reliabilitasnya. Data yang memenuhi kriteria inklusi (semua pertanyaan dijawab) kemudian dicatat dalam tabel, diolah dan dianalisis. Analisis univariat digunakan untuk mengetahui distribusi frekuensi pengetahuan, sikap dan praktik personal hygiene organ genitalia eksterna serta kejadian keputihan. Analisis bivariat yang digunakan adalah uji chi square dengan kemaknaan $\mathrm{p}<0,05$. 
Hasil

Tabel 1. Hubungan Pengetahuan Personal Hygiene dengan Kejadian Keputihan

\begin{tabular}{|c|c|c|c|c|c|c|c|}
\hline \multirow{4}{*}{ Pengetahuan } & \multicolumn{4}{|c|}{ Keputihan } & \multirow{2}{*}{\multicolumn{2}{|c|}{ Total }} & \multirow{4}{*}{$\mathrm{p}$} \\
\hline & & & & & & & \\
\hline & \multicolumn{2}{|c|}{ Normal } & \multicolumn{2}{|c|}{ Tidak Normal } & & & \\
\hline & $\mathrm{n}$ & $\%$ & $\mathrm{n}$ & $\%$ & $\mathrm{n}$ & $\%$ & \\
\hline Baik & 39 & 79,6 & 10 & 20,4 & 49 & 100 & \\
\hline Buruk & 10 & 20,4 & 39 & 79,6 & 49 & 100 & 0,000 \\
\hline Total & 49 & 50,0 & 49 & 50,0 & 98 & 100 & \\
\hline
\end{tabular}

$\mathrm{p}=$ Kemaknaan. $\mathrm{P}<0,05$

Tabel 2. Hubungan Sikap Personal Hygiene dengan Kejadian Keputihan

\begin{tabular}{|c|c|c|c|c|c|c|c|}
\hline \multirow{3}{*}{ Sikap } & \multicolumn{4}{|c|}{ Keputihan } & \multirow{2}{*}{\multicolumn{2}{|c|}{ Total }} & \multirow{3}{*}{$\mathrm{p}$} \\
\hline & \multicolumn{2}{|c|}{ Normal } & \multicolumn{2}{|c|}{ Tidak Normal } & & & \\
\hline & $\mathrm{n}$ & $\%$ & $\mathrm{n}$ & $\%$ & $\mathrm{n}$ & $\%$ & \\
\hline Baik & 46 & 65.7 & 24 & 34,3 & 70 & 100 & \\
\hline Buruk & 3 & 10.7 & 25 & 89,3 & 28 & 100 & 0,000 \\
\hline Total & 49 & 50.0 & 49 & 50,0 & 98 & 100 & \\
\hline
\end{tabular}

Kemaknaan. $\mathrm{p}<0,05$

Tabel 3. Hubungan Praktik Personal Hygiene dengan Kejadian Keputihan

\begin{tabular}{|c|c|c|c|c|c|c|c|}
\hline \multirow{3}{*}{ Praktik } & \multicolumn{4}{|c|}{ Keputihan } & \multirow{2}{*}{\multicolumn{2}{|c|}{ Total }} & \multirow{3}{*}{$\mathrm{p}$} \\
\hline & \multicolumn{2}{|c|}{ Normal } & \multicolumn{2}{|c|}{ Tidak Normal } & & & \\
\hline & $\mathrm{n}$ & $\%$ & $\mathrm{n}$ & $\%$ & $\mathrm{n}$ & $\%$ & \\
\hline Baik & 36 & 87.8 & 5 & 12.2 & 41 & 100 & \\
\hline Buruk & 13 & 22.8 & 44 & 77.2 & 57 & 100 & 0,000 \\
\hline Total & 49 & 50.0 & 49 & 50.0 & 98 & 100 & \\
\hline
\end{tabular}

$\mathrm{p}=$ Kemaknaan. $\mathrm{p}<0,05$

\section{Diskusi}

\section{Hubungan Pengetahuan Personal Hygiene dengan Kejadian Keputihan}

Pengetahuan atau kognitif merupakan faktor yang sangat berperan dalam membentuk tindakan seseorang. Perilaku yang didasari pengetahuan akan lebih baik dan permanen dibandingkan perilaku yang tidak didasari pengetahuan. ${ }^{9}$ Tingkat pengetahuan seseorang terhadap suatu objek dapat berbeda-beda. Hal tersebut dapat dipengaruhi beberapa faktor, diantaranya faktor usia, pendidikan, dan lingkungan. Pada penelitiannya, Khatibet al., ${ }^{10}$ menyatakan tingkat pendidikan orangtua juga berpengaruh dalam pengetahuan seseorang terhadap personal hygiene organ genitalia. 
Pada penelitian ini ditemukan hubungan antara pengetahuan tentang personal hygiene dan keputihan dengan kejadian keputihan patologis, peningkatan resiko 15,2 kali ( $\mathrm{p}=0,000$ $\mathrm{OR}=15,210 \mathrm{RR}=0,256)$ dari hasil analisa sederhana $(\mathrm{r})$ didapat korelasi antara tingkat pengetahuan dan kejadian keputihan adalah 0,592, hal ini menunjukkan terdapat hubungan antara pengetahuan dengan keputihan. Sedangkan arah hubungan adalah positif dengan kekuatan korelasi sedang, menunjukkan tingkat pengetahuan personal hygiene searah dengan kejadian keputihan. Penelitian sebelumnya dilakukan oleh Sukamto et al. ${ }^{9}$ tahun 2018 pada mahasiswi angkatan 2015-2018 Fakultas Kedokteran Universitas Sriwijaya menyatakan terdapat hubungan bermakna antara tingkat pengetahuan dengan kejadian keputihan $(\mathrm{p}=$ 0,015).Tingkat pendidikan merupakan salah satu faktor yang mempengaruhi pengetahuan. Semakin tinggi tingkat pendidikan seseorang maka akan semakin mudah seseorang menerima dan menyampaikan informasi tersebut kepada oranglain.Pernyataan ini sama dengan penelitian yang dilakukan oleh Mammen di Punjab India tahun 2017, menyatakan bahwa terdapat hubungan yang signifikan antara kejadian keputihan dengan tingkat pendidikan $(\mathrm{p}=$ $0.015) .^{11}$

\section{Hubungan Sikap Menjaga Personal Hygiene dengan Kejadian Keputihan}

Sikap merupakan respons terhadap suatu stimulus atau objek, sikap juga merupakan gambaran atau refleksi atas tindakan seseorang terhadap stimulus ataupun objek tersebut. Respons yang dihasilkan masih tertutup dan dipengaruhi oleh pengetahuan akan stimulus ataupun objek tersebut. Pada penelitian ini terdapat hubungan antara sikap menjaga personal hygiene organ genitalia eksterna dengan kejadian keputihan patologis dengan peningkatan resiko sebesar 15,9 kali $(\mathrm{p}=0,000 \mathrm{OR}=15,972 \mathrm{RR}=0,384)$ dan dari hasil analisa sederhana (r) didapat korelasi antara sikap dan kejadian keputihan adalah 0,497 Hal ini menunjukan terdapat hubungan antara sikap dengan keputihan. Sedangkan arah hubungan adalah positif dengan kekuatan korelasi sedang, berarti sikap personal hygiene searah dengan kejadian keputihan.

Penelitian sebelumya dilakukan oleh Purnama pada tahun 2016 pada siswi Madrasah Tsanawiyah (MTS) di Bantul menemukan terdapat hubungan bermakna antara sikap menjaga higiene seseorang dengan kejadian keputihan $(\mathrm{p}=0.046) .{ }^{12}$ Adapun penelitian lain sebelumnya dilakukan oleh Nurhayati tahun 2013 pada remaja putri usia 13-17 tahun di daerah Pondok Cabe Ilir tidak menemukan hubungan yang bermakna antara pengetahuan dengan kejadian keputihan $(\mathrm{p}=0.806) .{ }^{13}$ Dalam konteks penelitian ini, hasil berbeda di kedua sekolah bisa disebabkan oleh faktor pengalaman pribadi, orang lain, kebudayaan, media massa, lembaga pendidikan dan faktor emosional diatas memiliki distribusi yang berbeda. ${ }^{10}$

\section{Hubungan Praktik Personal Hygiene dengan Kejadian Keputihan}

Pada penelitian ini terdapat hubungan antara praktik personal hygiene organ genitalia eksterna dengan kejadian keputihan patologis, peningkatan resiko sebesar 24 kali ( $\mathrm{p}=0,000$ $\mathrm{OR}=24,369 \mathrm{RR}=0,158$ ) dari hasil analisa sederhana (r) didapatkan korelasi antara praktik dan kejadian keputihan adalah 0,592 Hal ini menunjukan terdapat hubungan antara sikap dengan keputihan. Sedangkan arah hubungan adalah positif dengan kekuatan korelasi kuat, berarti praktikpersonal hygiene searah dengan kejadian keputihan.

Pada penelitian sebelumnya dilakukan oleh Rahmah tahun 2017 pada santriwati MA di Enrekang, terdapat hasil yang bermakna antara praktik personal hygiene seseorang terhadap kejadian keputihan $(\mathrm{p}=0.000) .{ }^{14}$ Praktik personal hygiene genitalia adalah upaya untuk menjaga kebersihan genitalia dilakukan secara mandiri, berlandaskan pengetahuan dan pemahaman yang dimiliki oleh individu tersebut. ${ }^{6}$ Seperti sebelumnya telah dibahas, kekeliruan dalam hal ini menjadi faktor predisposisi dari terjadinya iritasi dan infeksi pada organ genitalia, termasuk keputihan. Hal ini sejalan dengan penelitian dilakukan di Mansoura 
University, Mesir pada tahun 2017 didapatkan hubungan yang signifikan antara praktik genital hygiene dengan kejadian keluhan keputihan $(\mathrm{p}=0.044)$, dari 500 responden 35,8\% membersihkan vagina dengan jemari dan $34,2 \%$ membersihkan hanya menggunakan air mengalir, 69,6\% menggunakan pakaian dalam terbuat dari katun dan 53,6\% menggantinya secara rutin, dan sebagian besar dari jumlah responden yaitu 96,2\% memotong rambut kemaluan secara rutin. ${ }^{15}$

\section{Kesimpulan}

Terdapat hubungan yang bermakna $(\mathrm{p}=0,000)$ dan korelasi positif antara tingkat pengetahuan, sikap dan praktik personal hygiene dengan kejadian keputihan patologis.

\section{Daftar Pustaka}

1. Abid M, Jyoti, Kumar K, Khan R, Ali S, Chandra P, et al. Assessment of leucorrhea diseases in female students. Int j sci innov res. 2016; 5(4): 68- 75

2. Ghotbi, S, Beheshti, M, Amirizade, S.Causes of leukorrhea in Fasa, Southern Iran. Shiraz EMedJ. 2007; 8(2):58-63

3. Rusdi NK, Trisna Y,Soemiati A. Pola pengobatan fluor albus di Rumah Sakit Umum Pusat Nasional Dr Cipto Mangunkusumo serta faktor-faktor yang mempengaruhinya (Analisis data rekam medik tahun 2006-2007). J Pharm Sci Res. 2012; 5(2): 91-100

4. BKKBN. Kajian Profil penduduk Remaja (10-24 tahun): Ada apa dengan remaja. Policy Brief Puslitbang kependudukan-BKKBN 2011;1

5. Paryono $\mathrm{P}$, Nugraheni I.Perilaku penggunaan tisu toilet terhadap kejadian keputihan pada remaja. JKK. 2016;1(1):25

6. Notoadtmodjo S. Ilmu Perilaku Kesehatan. Jakarta: Rineka Cipta. 2010

7. Notoadtmodjo S. Ilmu Kesehatan Masyarakat. Edisi Kedua. Jakarta: Rineka Cipta. 2003

8. Adolfsson A, Hagander A, Mahjoubipour F, Larsson P. How vaginal infections impact women's everyday life: Women's lived experiences of bacterial vaginosis and recurrent vulvovaginal Candidiasis, Adv Sex Med.2017;07(01):1-19

9. Sukamto NR, Yahya YF, Handayani D, Argentina F, Liberty IA. Hubungan pengetahuan, sikap dan perilaku perawatana vagina terhadap kejadian keputihan patologis pada mahasiswi Program Studi Pendidikan Dokter Fakultas Kedokteran Universitas Sriwijaya. MajKedoktSriwijaya. 2018;50(4):118

10. Khatib A, Adnani SS, Sahputra RE. Hubungan pengetahuan, sikap dan perilaku personal hygiene dengan gejala vaginitis pada Siswi SMPN 1 Kota Padang dan SMPN 23 Padang. JKesehatAndalas. 2019; VII (1):24

11. Mammen SA, Singh S, Rajesh I, Goyal S. Perception and correlates of excessive vaginal discharge in rural women. IntJReproductContracept ObstetGynecol. 2017; VI(8):3505

12. Purnama, OA. Hubungan pengetahuan, sikap, dan perilaku dengan kejadian keputihan patologis pada remaja putri kelas IX di MTSN Wonokromo Bantul. [Skripsi]. Yogyakarta: Universitas Gajah Mada. 2016

13. Nurhayati A. Perilaku vaginal hygiene terhadap kejadian keputihan patologis pada remaja putri usia 13-17 Tahun Di Daerah Pondok Cabe Ilir. [Skripsi].Tangerang:Universitas Islam Negeri Syarif Hidayatullah. 2013

14. Rahmah NF. Hubangan Pengetahuan dan perilaku personal kebersiha genital terhadap kejadian keputihan pada Santriwati SMAS/MA di PPM Rahmatul Asri Enrekang tahun 2017. [Skripsi]. Makasar: Universitas Hasanuddin. 2017

15. Zaher EH, Khedr NFH, Elmashad HMA. Awarnes of women regarding vaginal discharge.J NoursHealth Sci. 2017;VI:8 